\title{
FEDERAL ENFORCEMENT OF AIRLINE SYSTEM BOARD AWARDS UNDER THE RAILWAY LABOR ACT: THE SPECTER OF CHICAGO RIVER*
}

Section 184 of Title II of the Railway Labor Act requires that every collective bargaining agreement in the airline industry provide for a system board. ${ }^{1}$ The purpose of requiring that system boards be established is to encourage the peaceful settlement of disputes arising under existing collective bargaining agreements between unions and the airlines. ${ }^{2}$ But section 184 does not on its face reveal whether a suit to enforce an award of an airline system board can be brought in a federal district court as an action arising under the laws of the United States or an act of Congress regulating commerce. ${ }^{3}$ The Supreme Court has granted certiorari in International Ass'n of Machinists v. Central Airlines, Inc. ${ }^{4}$ to decide what appears to be a disarmingly narrow procedural questionwhether section 184 of Title II affords a federal right of enforcement for awards of airline system boards. ${ }^{5}$ But, as with most questions that concern the absence of clearly expressed congressional intent and a complex regulatory scheme, the question cannot be viewed so simply. For not only does the question involve a construction of other provisions of the RLA, of which Title II is only a part, but it also requires a consideration of the far reaching effects this decision may have on other related questions, such as whether an airline union may use self help in the form of a strike to enforce a system board award and whether any federal standard of review applies in proceedings brought in state courts or in federal courts under diversity jurisdiction to enforce these awards.

In International Ass'n of Machinists v. Central Airlines, Inc., ${ }^{\circ}$ a local airline adjustment board established pursuant to section 184 awarded six employees of the airline reinstatement and back pay. The company had discharged

*International Ass'rn of Mrachinists v. Central Airlines, Inc, 295 F.2d 209 (5th Cir. 1961), cert. granted, 369 U.S. 802 (1962).

1. Section 204, 49 Stat. 1189 (1936), 45 U.S.C. $\$ 184$ (1958) [hereinafter sometimes cited as RLA].

2. See $\S 201,49$ Stat. 1189 (1936), 45 U.S.C. $\$ 181$ (1958), which by its terms incorporates $\S 151$ (a) of title I of the RLA.

3. The wording of the section is:

It shall be the duty of every carrier and of its employees, acting through their representatives, .... to establish a board of adjustment of jurisdiction not execeding the jurisdiction which may be lawfully exercised by system, group, or regional boards of adjustment, under the authority of section 3, Title I, of this Act.

Such boards of adjustment may be established by agreement between employecs and carriers either on any individual carrier, or system, or group of carriers by air and any class or classes of its or their employees; or pending the establishment of a permanent National Board of Adjustment as hereinafter provided.

Section 204, 49 Stat. 1189 (1936), 45 U.S.C. § 184 (1958).

4. 295 F.2d 209 (5th Cir. 1961), cert. granted, 369 U.S. 802 (1962).

5. Brief for Respondent, p. 2.

6. 295 F.2d 209, 211 (5th Cir. 1961), cert. granted, 369 U.S. 802 (1962). 
the men for refusing to work overtime and for not appearing at a hearing subsequently held by the company. ${ }^{7}$ At this hearing the company had refused to allow union representatives to accompany the employees; the adjustment board ruled that this refusal resulted in an improper procedure for discharge and thus was a breach of the collective bargaining agreement in force between the parties. ${ }^{8}$ Although the collective agreement provided that the award of the board was to be final and binding upon the parties, ${ }^{0}$ the company refused to comply, claiming that the board had exceeded its jurisdiction and had not adequately considered the merits of the case. ${ }^{10}$ The union sued for enforcement in a federal district court, asserting as the basis for federal jurisdiction that the act requiring the establishment of the adjustment boards also required that the awards of the board be afforded finality as a matter of federal law. ${ }^{11}$ This a suit to enforce an award of the board was a civil action that "arises under the ... laws . . o of the United States"12 or a "proceeding arising under any act of Congress regulating commerce," as those terms are used in statutes conferring original jurisdiction on federal district courts. ${ }^{13}$ By gaining a fecleral forum, the union apparently believed it would obtain a more uniform and more limited review of system board awards. The company, perhaps believing that state courts would afford a greater scope of review to the award, moved to dismiss on the ground that any right of enforcement was derived solely from the terms of the contract between the parties and not from the act, ${ }^{14}$ since only the contract between the parties stated that the awards of the board were to be final and binding. The district court dismissed for want of jurisdiction and the Court of Appeals for the Fifth Circuit affirmed on the ground that the fact that federal law required the establishment of the system board was not by itself sufficient to confer federal question jurisdiction on a federal court in a stuit to enforce awards of the board. ${ }^{15}$

The Fifth Circuit, which ruled in Central Airlines that the finality of system board awards was derived from the agreement between the parties so that a suit on the award was not a sufficient basis for federal jurisdiction, had

7. Ibid.

8. Ibid.

9. Record on Certiorari, p. 8. Such clauses appear to be the general rule.

Every contract since 1936 covering the Air Line Pilots Association; which now has approximately 15,000 pilots as members, has included a provision making awards of a system board final and binding. Brief for the ALPA as Amicus Curiae, p. 2. No case has been found where an agreement establishing a system board has not provided that awards are to be final and binding.

10. Record on Certiorari, p. 30.

11. Brief for Petitioners, p. 27.

12. International Ass'n of Machinists v. Central Airlines, Inc., 295 F.2d 209, 210 (5th Cir. 1961), cert. granted, 369 U.S. 802 (1962).

13. See Judiciary Act of 1948, $\S \S 1331,1337,62$ Stat. 930 (1948), 28 U.S.C. $\S \S 1331$, 1337 (1958).

14. Record on Certiorari, p. 29.

15. International Ass'n of Machinists v. Central Airlines, Inc., 295 F.2d 209, 218 (5th Cir. 1961), cert. granted, 369 U.S. 802 (1962). 
previously viewed the effect to be afforded a system board award as something more than a matter of contract between the union and the airline. The appellate court in Sigfred v. Pan Am. World Airways, Inc. ${ }^{10}$ had held that the finality of these awards was entitled to protection as a matter of federal law and had established a federal standard of very limited review for system board awards. ${ }^{17}$ In Sigfred a union member was suing, with jurisdiction based on diversity of citizenship, to have an adverse award set aside. Since it was a diversity case, it was alleged that state law providing for a broad standard of review should apply. ${ }^{18}$ In holding that a federal standard governed, the court stated:

It becomes plain upon a moment's reflection that . . . a [state] system of review would completely sweep aside Congress's efforts to provide for a prompt and orderly settlement of labor disputes by system boards of adjustment. ${ }^{19}$

Presumably this holding that a federal standard governs the review of system board awards also applies to suits brought in state courts and thus assures protection to the awards against de novo or broad review in state courts. The unions have nevertheless expressed dissatisfaction with the unavailability of federal forums, save where diversity jurisdiction is present, for review of these awards. ${ }^{20}$ This dissatisfaction stems from the fact that, even if the need for a federal standard of limited review is recognized, enforcement suits, absent diversity jurisdiction, are governed by the variegated views of fifty state courts as to what the federal standard for review is and how it should be applied.21 A union is especially at a disadvantage in such a situation. While it must wait to see if the carrier will comply with the award before being able to sue for enforcement, the carrier can choose the most favorable state forum available in which to sue to set aside the award.22 It probably is this disuniformity, allowing greater review by the state courts, that underlies the union's desire in Central Airlines to establish that federal law confers finality on system board awards so that a federal forum will be readily available for enforcement suits.

For a case to arise under the laws of the United States or an act regulating commerce, the plaintiff must base his complaint on a substantial claim to a right

16. 230 F.2d 13 (5th Cir.), cert. denied, 351 U.S. 925 (1956).

17. The majority stated that unless some question was raised concerning the system board's jurisdiction or the regularity of its proceedings, there would be no review of the board's rulings of law. Id. at 17 .

18. Id. at 15.

19. Id. at 17 .

20. Petition for Certiorari, p. 11, International Ass'n of Machinists v. Central Airlines, Inc., 295 F.2d 209 (5th Cir. 1961), cert. granted, 369 U.S. 802 (1962).

21. For a discussion of the possibility for differing results in state courts see Mishlin, The Federal "Question" in the District Courts, 53 Coluar. L. Rev. 157, 172 (1953).

22. The carrier in the instant case had filed suit in a state court to set aside the award prior to the union's suit to enforce the award. Petition for Certiorari, p. 11, n.2, Intermational Ass'n of Machinists v. Central Airlines, Inc, 295 F.2d 209 (5th Cir. 1961), ccrt. gronted, 362 U.S. 802 (1962). 
granted by a federal statute. ${ }^{23}$ Because the interpretation of a federal statute is frequently drawn in question in these cases, this requirement is often phrased in terms that a plaintiff must succeed on one construction of the statute and fail on another in order to establish "federal question" jurisdiction. ${ }^{24}$ This characterization - "federal question" jurisdiction-and this phrasing of the requirement are both confusing and misleading. For the question of jurisdiction ultimately depends upon whether the plaintiff's suit is based upon a right granted, whether explicitly or implicitly, by the federal statute, and not upon whether the statute must be construed in order to determine if the plaintiff has a federal right or not. ${ }^{25}$ Under this analysis, the court of appeal's statenent in Central Airlines that the existence of a board established pursuant to a fed. eral statute is not determinative of whether a suit to enforce an award of the board is based upon a federal right seems correct. If the union were sting to

23. E.g., Skelly Oil Co. v. Phillips Petroleum Co., 339 U.S. 667 (1950) ; Bell v. Hood, 327 U.S. 678 (1946).

24. E.g., Gulley v. First Nat'l Bank, 299 U.S. 109 (1936) ; Shulthis v. MeDougal, 225 U.S. 561, 569 (1912). See generally 2 Moore, Federal Practice If 2.07 (2d ed. 1962); anm notation to 28 U.S.C.A. \$ 1331 n.35 (1949).

25. See Mishkin, The Federal "Question" in the District Cottrt, 53 ConUM. L. REv. 157, 166, 170-71 (1953); London, "Federal Question" Jurisdiction-A Snare and a Delusion, 57 Mrch. L. REv. 835 (1959). The cases cited in note 24 supra, taken literally, would require a dispute over the existence of the federal right sought before there could be federal question jurisdiction. This would mean that once a right is clearly established, its existence no longer would be controverted so that a suit to enforce that right would not be one arising under the laws of the United States.

It is very possible that this means there could be a federal right with no forum to enforce it. While Testa v. Katt, 330 U.S. 386 (1947), held that state courts could not discriminate against federal rights, Douglas v. New York, N.H. \& H.R.R., 279 U.S. 377, 387 (1929), held that a state did not have to enforce a federal right if it did not enforce similar state rights. State courts generally will not enforce any future agreement to arbitrate. Sce generally Sturges, Commercial Arbitration and Awards $\$ \$ 15,18,76-83$ (1930). Texas, the state in question here, follows this policy of non-enforcement. Tejas Development Co. v. McGough Bros., 165 F.2d 276 (5th Cir. 1947).

Therefore state courts would not compel the establishment of the system boards. Yet, since the right and duty to establish them is not subject to dispute, under the theory above there would be no federal question jurisdiction for an enforcement suit. Since there was also no diversity jurisdiction possible for the union in Central Airlines, if the union had needed to compel the establishment of the system board, there would have beer no way to effectuate the federal right.

Naturally the criteria for cases arising under the laws of the United States have not been so limited. In Steele v. Louisville \& N.R.R., 323 U.S. 192 (1944), the right to fair representation under the RLA was clearly established. Tunstall v. Brotherhood of Loc. Eng'rs., 323 U.S. 210, 213 (1944), held that this right was sufficient to confer jurisdiction upon federal courts for its enforcement. And, rather than subsequently denying jurisdiction, federal courts have continued to allow federal jurisdiction in suits to enforce this clearly established right. See, e.g., Hostetler v. Brotherhood of R.R. Trainmen, 287 F.2d 457, 458 (4th Cir. 1960), cert. denied, 368 U.S. 955 (1962) ; Richardson v. Texas \& N.O.R.R., 242 F.2d 230, 234 (5th Cir. 1957) ; Hargrove v. Brotherhood of Locomotive Eng'rs., $116 \mathrm{~F}$. Supp. 3,8 (D.D.C. 1953). Cf. American Well Works Co. v. Layne \& Bowler Co., 241 U.S. 257 (1916). 
compel the company to cooperate in establishing a system board, as required by section 184, the suit would clearly be one arising under the laws of the United States or an act regulating commerce, since the union's claim would be squarely based upon the statute providing that " [i]t shall be the duty of every carrier ... to establish a Board of Adjustment."20 However, though federal law requires the establishment of the boards, so that an action based upon an award of a board is indirectly derived from federal law, the question of whether a suit to enforce the award "arises under" such law nevertheless depends on whether the statute confers a federal right of enforcement for these awards. And this question in turn depends upon whether section 184 makes system board awards final and binding. When an award is final and binding, absent some constitutional or procedural irregularity, a board's decision and order for relief is conclusive on the parties as to the merits of the controversy. ${ }^{27}$ If the decision of the system board is made final and binding on both parties as a matter of federal law, federal law imposes a duty on the parties to comply with the awards of system boards and confers a corresponding right on a party to seek redress for breach of the duty. Therefore a suit to enforce the award against a noncomplying party is based upon a right conferred by federal law. ${ }^{23}$ But if the statute does not make the awards final and binding and thus afford a federal right of enforcement, the actual basis for the suit is the collective agreement; an action based on that agreement, even if it makes the awards final and binding, is not one arising under the laws of the United States or an act regulating commerce.

Section 184 of Title II does not state whether airline system board awards are to be final and binding, ${ }^{29}$ and the scant legislative history on this section makes no mention of the effect to be given these awards. ${ }^{30}$ However, Title II was added to the Railway Labor Act in 1936 to cover the small but expanding airline industry on the theory that this transportation industry was sufficiently similar to the railroads to require the same regulatory scheme governing labormanagement relations. ${ }^{31}$ At that time the railroads were governed by Title I of the RLA, ${ }^{32}$ and most of the provisions of Title I were incorporated by refer-

26. 49 Stat. 1189 (1936), 45 U.S.C. § 184 (1958).

27. See Sigfred v. Pan Am. World Airways, Inc., 230 F.2d 13, 16 (5th Cir.), cerf. denied, 351 U.S. 925 (1956) ; Brand v. Pennsylvania R.R, 22 F. Supp. 569 (E.D. Pa. 1938); Ellerd v. Southern Pac. R.R., 241 F.2d 541 (7th Cir. 1957).

28. See note 25 supra and Graham v. Brotherhood of Loc. Firemen, 338 U.S. 232 (1949) ; Switchmen's Union v. National Med. Bd., 320 U.S. 297 (1943) ; Virginian Ry. v. System Fed. \# 40, 300 U.S. 515 (1937) for examples of federal courts enforcing rights granted by the RLA.

29. See the wording of $\$ 184$, supra note 3.

30. See Hearings on S. 2496 Before a Subcommittee of the Senate Commiltee on Interstate Commerce, 74th Cong., 1st Sess. (1935).

31. Hearings on S. 2496 Before a Subcommittee of the Senate Committee on Interstate Connmerce, 74th Cong., 1st Sess. 4, $26-27$ (1935). For an expression of dissatisfaction with the subsequent results of the application of the RLA to airlines sce AracIntyre, The Railway Labor Act-A Misfit for the Airlines, 19 J. Axr L. \& Coss. 274 (1952).

32. 48 Stat. 1185 (1934), 45 U.S.C. \$§ 151-64 (1958), amending 44 Stat. 577 (1926). 
ence into Title II. ${ }^{33}$ Section 184 of Title II finds its counterpart in section 153 of Title I, which establishes the procedures governing the settlement of labor disputes arising under collective agreements between rail carriers and unions. ${ }^{34}$ An examination of Title $I$ and the events leading to the passage of section 153 furnishes a basis for deciding whether section 184 confers finality upon awards of an airline system board. Such an examination will also shed light upon some of the ripple effects a determination of the issue involved in the principal case may have.

As originally passed in 1926, the Railway Labor Act stressed voluntary procedures for the settlement of labor disputes between railroads and unions, ${ }^{\text {at }}$ Thus, the act established a Federal Board of Mediation to propose solutions on both disputes concerning the formation of a collective bargaining agreement -major disputes-and those arising under an existing agreement-minor disputes. $^{36}$ It also allowed the parties to establish system boards to decide minor disputes. ${ }^{37}$ Where no system board had been established or where the system board, composed of an equal number of representatives of the union and carrier, was deadlocked, the dispute was to be referred to the Board of Mediation, whose resolution was not binding. ${ }^{38}$ After eight years the Board of Mediation had become inundated because of the ineffectiveness of this wholly voluntary procedure. ${ }^{39}$ The carriers had often refused to establish system boards; the few boards that were established had no means of breaking the deadlocks that commonly occurred. ${ }^{40}$ The act was amended in 1934 to provide a more effective procedure for the peaceful resolution of minor disputes. Instead of providing for the mandatory establishment of system boards, the act required that a national adjustment board, composed of an equal number of representatives from unions and carriers, be established. ${ }^{41}$ Deadlocks on this National Railroad Ad-

33. 49 Stat. 1189 (1936), 45 U.S.C. $\$$ 181-82 (1958).

34. 48 Stat. 1189 (1934), 45 U.S.C. \& 153 First (1958).

35. 44 Stat. 578 (1926). For a complete collection and discussion of railway labor legis4 lation prior to 1926 see U.S. Attorney General's Committee on Administuative Procedure, Inquiry Relating to the National Railroad Adjustarent Bonkd: Book II (1941).

36. Section 5, 44 Stat. 580-82 (1926). The terms "major" and "minor," while not contained in the statute, have been used to describe the two classes of disputes. Sec, c.g., Elgin, J. \& E. Ry. v. Burley, 325 U.S. 711, 723 (1945). For a recent exploration of the problems created by this division see McGuinn, Injunctive Powers of the Federal Courts In Cases Involving Disputes Under The Railway Labor Act, 50 GEo. L.J. 46 (1961).

37. Section 3 First, 44 Stat. 578-79 (1926).

38. Section 5 First, 44 Stat. 580 (1926).

39. Elgin, J. \& E. Ry. v. Burley, 325 U.S. 711, 725-26 (1945).

40. Hearings on $S .3266$ Before the Senate Committee on Interstate Commerce, 73d Cong., 2d Sess. 15-17 (1934).

41. 48 Stat. 1189 (1934), 45 U.S.C. § 153 First (1958). The NRAB is broken down into four divisions operating independently of each other. The divisions are for various classes of employees. 48 Stat. 1190-91 (1934), 45 U.S.C. \& 153 First (h) (1958). The national character of the Board was primarily the demand of the unions who believed that their interests would be better protected by a national body. The carriers agreed that compulsory boards ought to be established, but wanted them on a local basis so as to be better 
justment Board (NRAB) were avoided by provisions for the appointment of a neutral referee when needed.\$2 Although the Board's jurisdiction was optional in the sense that a dispute did not have to be submitted to it, ${ }^{43}$ when either party submitted a dispute, the other was compelled to appear and was bound by the award of the Board." In addition, there was a provision in the act allowing the parties to agree upon the establishment of a system board, ${ }^{45}$ which would exempt them from the jurisdiction of the NRAB.to If either party subsequently objected to the operation of such a system board, however, he could again come under the jurisdiction of the NRAB by simply giving a ninety-day notice of such an intention. 47

The establishment of the NRAB by section 153 First of the RLA was envisaged by Congress as representing a procedure for the compulsory arbitration of minor disputes. ${ }^{48}$ In keeping with the nature of effective arbitration, the awards of the NRAB were made final and binding upon the parties to the dispute by subsection (m)..$^{49}$ This subsection thus imposes a duty of compliance upon the parties and therefore provides a basis for federal jurisdiction in a suit to enforce an NRAB award. ${ }^{50}$ However, Congress was more explicit on the

able to handle local problems. Garrison, The National Railroad Adjustment Board: A Unique Adninistrative Agency, 46 YALE L.J. 567, 574-75 (1937). As a compromise to the carriers, it was provided that, if agreement could be reached, the NRAB would establish regional boards. 48 Stat. 1193 (1934), 45 U.S.C. $\$ 153$ First (w) (1958).

42. 48 Stat. 1191 (1934), 45 U.S.C. \& 153 First (1) (1958).

43. The wording of the act is that "the disputes may be referred by petition of the parties ... " 48 Stat. 1191 (1934), 45 U.S.C. $\$ 153$ First (i) (1958). However, the Supreme Court in 1950 held that the NRAB has exclusive jurisdiction over disputes involving the interpretation or application of collective bargaining agreements except in the limited area of suits for wrongful discharge. Slocum v. Delaware, L. \& IW.R.R, 339 U.S. 239 (1950). Then in 1957, a union's strike over a minor grievance was enjoined. Brotherhood of R.R. Trainmen v. Chicago R. \& I.R.R., 353 U.S. 30 (1957). The result is that the parties may have no alternative to adjustment by the NRAB.

44. Since subsection (m) of $\S 153$ First makes awards final and binding, the sceond party to the dispute has to appear to protect his interests. 48 Stat. 1191 (1934), 45 U.S.C. \& 153, First (m) (1958).

45. 48 Stat. 1193 (1934), 45 U.S.C. \& 153 Second (1958).

46. Atlantic Coast Line R.R. v. Pope, 119 F.2d 39 (4th Cir. 1941); Hearings on $S$. 3266, supra note 40, at 34; H. R. Rer. No. 1944, 73d Cong., 2d Sess. 3-4 (1934).

47. 48 Stat. 1193 (1934), 45 U.S.C. § 153 Second (1958).

48. Brotherhood of R.R. Trainmen v. Chicago River \& I.R.R., 353 U.S. 30,39 (1957); Hearings on H.R. 7650 Before the House Committee on Interstate and Forcign Commerec, 73d Cong., 2d Sess. 58 (1934).

49. 48 Stat. 1191 (1934), 45 U.S.C. $\$ 153$ First (m) (1958) ; Union Pac. R.R. v. Price, 360 U.S. 601,616 (1959). The great need for finality is also discussed in Gregory \& Orlikoff, The Enforccment of Labor Arbitration Agreements, 17 U. Cur. L. REv. 233, 233 (1950). Compare the Supreme Court's recognition of the importance of arbitration agreements and the need to give binding effect to resulting awards in the "Steelworkers Trilogy," United Steelworkers of America v. American Mffg. Co., 363 U.S. 564 (1960); United Steelworkers of America v. Warrior and Gulf Nav. Co., 363 U.S. 574 (1960); United Steelworkers of America v. Enterprise Wheel and Car Corp., 363 U.S. 593 (1960).

50. See notes 23-28 supra and accompanying text. 
question of federal jurisdiction. Section 153 First goes on to state in subsection (p) that when a carrier refuses to comply with an award, the union may bring an enforcement suit in a federal court, and in this suit, the Board's award is to serve as prima facie evidence for the union. ${ }^{61}$. While clearly establishing federal jurisdiction for suits brought by the union, this subsection also grants a much broader scope of review than would otherwise be available and therefore undercuts the finality afforded NRAB awards by subsection $(\mathrm{m}){ }^{\mathrm{ta}}$ Whatever the reason for the inconsistency between subsections $(m)$ and $(p),{ }^{63}$ since federal courts give only limited review when the unions lose, ${ }^{54}$ the effect of these two provisions is that there is limited judicial review when a union loses and broad review when it prevails before the Board. Because the enforcement procedure of subsection ( $p$ ) places a burden upon the unions to litigate their claims twice, unions generally do not sue for enforcement of $\mathrm{NRAB}$ awards. Instead they strike, either before submitting the dispute to the Board or after receiving an award from it. ${ }^{55}$ Carriers have not sought to enforce awards of the

51. 48 Stat. 1192 (1934), 45 U.S.C. \& 153 First (p) (1958). To make it casier for employees and unions to bring their suits, this section also provides that the petitioner shall not be liable for costs in any event and shall receive, if successful, reasonable attorney's fces.

52. For statements to this effect see Penmsylvania R.R. v. Day, 360 U.S. 548, 558-59) (1959) (dissenting opinion); Dahlberg v. Pittsburg \& L.E.R.R., 138 F.2d 121 (3d Cir. 1943) ; Northrup \& Kahn, Railroad Grievance Machinery: A Critical Analysis-II, 5 INv. \& LAB. ReI. Rev. 540 (1952). The limited grounds for review of common law arbitration awards is discussed in Sturges, Commerctal Arbitrations and A wards \$\$ 366-68 (1930). For cases where a federal court, in an enforcement proceeding, has reversed an adjustment board award see Dahlberg v. Pittsburg \& L.E.R.R., supra; Brotherhood of Ry. \& S.S. Clerks v. Railway Express Agency, 238 F.2d 181 (6th Cir. 1956). It should be noted, though, that in most cases the carriers willingly comply with adverse awards. BunuN, Labor Disputes and Their Settlement 185 (1955) ; Spencer, The National Railiond AdjustMent Board 56 (1938).

53. While the existence of subsection (p) might be explained as an effort to guarantec federal courts jurisdiction, see Kroner, Minor Disputes Under the Railzway Labor Act: A Critical Appraisal, 37 N.Y.U.L. Rev. 41, 71 (1962), this would appear unnecessary in light of the broad grant of jurisdiction granted by 28 U.S.C. $\$ 1337$ and would not explain why the awards were only to be prima facie evidence. In $\$ 159$ of the RLA, for example, arbitration awards resulting from agreements by parties to arbitrate disputes over the formation of contract provisions are conclusive on the parties as to the merits and facts of the controversy. 44 Stat. 585 (1926), 45 U.S.C. § 159 Second (1958).

54. See, e.g., Ellerd v. Southern Pac. R.R., 241 F.2d 541 (7th Cir. 1957) ; Brand v. Pennsylvania R.R., 22 F. Supp. 569 (E.D. Pa. 1938). Subsection (m) states that money awards are not to be final and binding, but the Supreme Court has recently affirmed that a denial of an employee's money claim is not a "money award" within the terms of the act so that the denial is final and binding. Union Pac. R.R. v. Price, 360 U.S. 601,608 (1959). And the federal courts have treated grants of money awards in enforcement suits similarly to non-money awards so that the wording appears useless. See Brotherhood of R.R. Trainmen v. Chicago River \& I.R.R., 353 U.S. 30, 32 (1957); Brotherhood of R.R. Trainmen v. Denver \& R.G.W.R.R., 290 F.2d 266, 267 (10th Cir. 1961), cert. denticd, 366 U.S. 966 (1961), amictus brief filed and rehearing denicd, 368 U.S. 873 (1961).

55. Spencer, The National Railroad Adjustment Board 56 (1938); Hearings on S. 3463 Before a Subcommittee of the Senate Committee on Labor and Public Welfarc, 81st Cong., 2d Sess. 76-77, 88, 299 (1950); Braun, Labor Disputes and Tietr SetrleMENT 221 (1955). 
Board, primarily because the nature of minor grievances are such that an "award" for the carrier will generally be in the form of denying an affirmative union claim. ${ }^{56}$

The use of strikes by unions has not gone unnoticed. In 1950 a bill was proposed prohibiting strikes over disputes under the RLA, granting limited judicial review to all affected by an NRAB award whether favorably or adversely, and establishing compulsory arbitration of major disputes. feated because of the provision for compulsory arbitration. ${ }^{58}$ Then in 1957 the Supreme Court held, in Brotherhood of R.R. Trainmen v. Chicago River \& I.R.R. ${ }^{59}$ that since Congress had provided an exclusive administrative remedy for the settlement of minor disputes under the RLA, a union could be enjoined from striking over a pending dispute that had been submitted by a carrier to the NRAB. ${ }^{60}$ The Court did not pass on the question of whether a strike to enforce an award of the NRAB could similarly be enjoined. Two circuit courts, however, have extended the doctrine of Chicago River to such strikes on the ground that the judicial procedure provided in the RLA is the exclusive means for enforcing awards of the NRAB and that strikes in lieu of resolution of disputes by the NRAB or of judicial enforcement of NRAB awards are inconsistent with the system of compulsory arbitration provided in section 153 First. This extension of Chicago River to enforcement strikes is now before the Supreme Court in the case of Louisville \& N.R.R. v. Brotherhood of Loc. Eng'rs. ${ }^{61}$ The result for railroad unions, if it is upheld, is that the procedure of subsection ( $p$ ), which formerly was only an alternative means of enforcement whose inequities were not worth attacking, will now be the sole method of enforcement available. ${ }^{62}$

The strike weapon is especially effective under the RLA because once a strike is threatened, the NMB can make a finding that a labor emergency exists and enter the dispute to press for settlement. 49 Stat. 1189 (1936), 45 U.S.C. $\$ 183$ (1958) ; sce SpExcER, supra at 56. Since an award on the merits has already been issued in favor of the union, the carrier is at a distinct disadvantage in this non-judicial proceeding. Northrup \& Kahn, supra note 52 , at 541 .

56. Since the carrier determines the status quo under the collective bargaining agreement by determining seniority rights, work rules, or rates of pay according to its interpretation of the agreement, the union will be the party secking a different interpretation of the contract if there is a disagreement.

57. S. 3463, 81st Cong., 2d Sess. (1950).

58. See generally Hearings on $S$. 3463, supra note 55; S. REp. No. 2445, 81st Cong., $2 d$ Sess. (1950) (unfavorable).

59. 353 U.S. 30 (1957).

60. For the subsequent history of this doctrine and the problems it has caused see Kroner, Minor Disputes Under the Raila'ay Labor Act: A Critical Appraisal, 37 N.Y.U.L. REv. 41 (1962) ; McGuinn; Injunctive Powers of the Federal Courts in Cases Invoking Disputes Under the Railway Labor Act, 50 Geo. L.J. 46 (1961).

61. 190 F. Supp. 829 (W.D. Ky.), aff'd per curiam, 297 F.2d 608 (6th Cir. 1961), cerl. granted, 370 U.S. 908 (1962). The other case was Brotherhood of R.R. Trainmen v. Denver \& R.G.W.R.R., 290 F.2d 266 (10th Cir.), cert. denicd, 366 U.S. 966, amicts bricf filed and rehearing denied, 368 U.S. 873 (1961).

62. The existence of a detailed enforcement procedure would appear to be as "exclusive" as the administrative remedy that was the basis for Chicago River. However, if the under- 
In contrast to the detailed procedure in section 153 First, section $153 \mathrm{Sec}-$ ond, which allows the parties to agree upon the establishment of system boards to decide minor disputes in lieu of the NRAB, is silent on the legal effect of awards rendered by these boards. ${ }^{63}$ What little legislative history there is for section 153 Second indicates that the parties were to be given the right to decide whether or not these awards were to be final and binding. ${ }^{64}$ This choice by the parties, coupled with the fact that the existence of a system board exempts the NRAB from jurisdiction, leads to the result that the parties through agreement can avoid whatever finality is afforded by section 153 First. Thus the policy of compulsory arbitration which appears to be embodied in section 153 First seems undermined. But it should not be overlooked that either party can reinstate the NRAB's jurisdiction and thus the finality of section 153 First by giving notice to the other party of its intention to do so.00 Therefore, if one side should refuse to comply with a system board award on the ground that it was not made final by agreement, the other coutd then dissolve the system board and return to the NRAB.

The broad purpose of Title II of the RLA was to bring labor-management relations in the airline industry under the same pattern of regulation as had been applied to the railroads under Title $I^{.66}$ Moreover, the alterations in Title II before its passage indicate that it was based upon the procedures of sections 153 First and Second governing minor disputes in the railroad industry. The initial structure of Title II basically followed the design established by the 1934 amendments to the RLA. There was to be a national air transport adjustment board similar to the NRAB and the parties were to be allowed to establish system boards as a substitute for the jurisdiction of the national board. The awards of the national air board were to be final and binding on the parties and the same enforcement procedures provided in section 153 First were to be ased.07 But the establishment of the national airline board was postponed because of the small size of the industry in $1936 ; 8$ a provision giving the National Mediation Board the power to create the National Air Transport Adjustment Board when the NMB deems it appropriate was incorporated in Title II. ${ }^{00}$ In the

lying premise of Chicago River was that the merits of a dispute were not to be decided by economic force, see Sinclair Ref. Co. v. Atkinson, 370 U.S. 195, 205-11 (1962), once ath award is made there is no such danger. Against this argument for denying an injunction in the Louisville \& Nashville case is the overriding goal of the RLA for the peaceful settlement of disputes. Also, a uniom enforcement strike denies a carrier the judicial revicw accompanying an enforcement suit so that economic force is still being used to decide the merits of the dispute.

63. 48 Stat. 1193 (1934), 45 U.S.C. § 153 Second (1958).

64. Hearings on $S$. 3266 , supra note 40 , at 34 ; Hearings on H.R. 7650, supra note 48 , at 88-89.

65. 48 Stat. 1193 (1934), 45 U.S.C. § 153 Second (1958).

66. See note 31 stipra.

67. S. 2496, 74th Cong., 1st Sess. (1935).

68. Hearings on S. 2496, supra note 31, at 4; H.R. REP. No. 2245, 74th Cong،, 2d Sess. 1 (1935).

69. 49 Stat. 1189 (1936), 45 U.S.C. \& 185 (1958). 
interval, the NMB was to have jurisdiction over all airline disputes ${ }^{70}$ with the parties being able to establish system boards if they so desired. ${ }^{\mathbf{1 1}}$ Because of the experience with this voluntary procedure under the RLA prior to the passage of sections 153 First and Second in $1934,{ }^{72}$ however, the bill was amended to provide for a less voluntary procedure for the settlement of minor disputes. Rather than compelling the establishment of the national adjustment board according to the 1934 pattern, though, a variation was adopted that required the establishment of the system boards, at least pending the establishment of the NATAB by the NMB.73

It is through this variation in section 184 of the procedures of section 153 that Congress tried to assure that labor disputes in the airline industry would be resolved in a manner similar to the resolution of disputes in the railroad industry. ${ }^{74}$ Unfortunately, Congress did not state whether this similar treatment was to be achieved by equating the awards of the airline system boards with those of the NRAB or with those of the voluntarily established railroad system boards. If the former, the awards should be entitled to the weight given those of the NRAB by federal law; if the latter, whatever weight they have will be derived only from the contract between the parties establishing the system boards. Arguably the procedures of section 184 can be equated with the railroad system boards of section 153 Second, since the definition of the jurisdiction of air system boards is put in terms of "not exceeding the jurisdiction which may be lawfully exercised by system, group, or regional boards of adjustment, under the authority of Section 3, Title I, of this act" $;^{75}$ the adjustment boards referred to are the boards which may be voluntarily established by parties under section 153 Second. However, equating the airline boards with the railroad system boards will not assure a similar procedure for the resolution of minor disputes. While section 153 Second leaves the question of finality to be determined by the parties, ${ }^{78}$ if one of the parties is dissatisfied with system board awards because they lack finality, he has the choice of moving from the jurisdiction of the system board to the jurisdiction of the NRAB whose awards are final and binding. ${ }^{77}$ However, parties to the awards of airline system boards have no such alternative, for there is no national board in

70. Hearings on $S .2496$, supra note 31 , at 3.

71. S. 2496, 74th Cong., 1st Sess. (1935).

72. Hearings on $S .2496$, supra note 31 , at 11 .

73. 49 Stat. 1189 (1936), 45 U.S.C. \$ 184 (1958).

74. Hearings on $S .2496$, stpra note 31 , at 12 .

75. 49 Stat. 1189 (1936), 45 U.S.C. § 184 (1958). The use of the words "not excceding" was unfortunate as it implies that the boards could have less jurisdiction. If this were so, the policy of the act of providing adjustment boards for the settlement of disputes would be defeated since parties could establish boards with no jurisdiction. Therefore, in light of the use of the same wording in $\S 185$ in reference to the NATAB which is recognized as being equivalent to the NRAB, see Metcalf v. National Airlines, Inc, 271 F.2d 817 (5th Cir. 1959), the words should be interpreted as meaning "the same and no more than the same."

76. See note 64 supra.

77. 48 Stat. 1193 (1934), 45 U.S.C. § 153 Second (1958). 
existence whose jurisdiction can be invoked. In the absence of an air national board equivalent to the NRAB, the air system boards are the sole means by which to effectuate the peaceful settlement of minor disputes, not an alternative method to be voluntarily selected by parties. For this reason it would seem that the procedures of section 184 are far more equivalent to those of 153 First than to those of 153 Second. ${ }^{78}$ In addition, the establishment of both the NRAB and the air system boards is compelled by federal law in an effort to provide for the peaceful settlement of disputes. The compulsory establishment of the air system boards was an effort to fill the gap left by the delayed establishment of the NATAB which, by the terms of Title II, was to afford adjust ment board awards the same weight and enforcement procedures as those outlined for the NRAB. This gap will not be filled and there will not be a similar resolution of minor disputes in the airline and railroad industries if the awards of the required air adjustment boards are not given the same weight or provided with the same enforcement procedure as the awards of the reqtired railroad adjustment board, the NRAB.

Finding that the procedures of section 184 should be equated with those of section 153 First in order to insure the similar treatment of grievances in the airline and railroad industries would mean that the awards of air system boards are to be afforded the same weight as those of the NRAB. The incorporation of subsection $(\mathrm{m})$ of section 153 First into section 184 would thus confer finnlity on the awards of air system boards and federal jurisdiction would therefore be established for suits to enforce these awards. But such a finding would also undermine the finality of awards sought to be enforced by the unions. For

78. For statements that the procedures of the NRAB are to be applied to $\S 184 \mathrm{sce}$ Bates v. Northwest Airlines, Inc., 171 F. Supp. 273, 274 (D. Minn. 1959) ; U.A.W. v. Delta Airlines, Inc., 83 F. Supp. 63 (N.D. Ga. 1949). But see Metcalf v. National Airlines, Inc., 271 F.2d 817 (5th Cir. 1959).

For every method of statutory construction there is a countervailing method for reaching the opposite conclusion. This has been illustrated in detail by LLEwellyN, TIIE COMaron Law Tradition-Deciding Appeals 522-35 (1960). So, here, the comparison of the explicit clauses of $\S 153$ First with the silent $\S 184$ can prove that Congress intencled to imply a right in $\S 184$ or that Congress meant to reject that right in $\S 184$. In light of the specific attempt to equate the two sections, however, the former construction should apply. The courts have also surrounded the NRAB and the compulsory system boards of $\$ 184$ with the same safeguards. The boards are given exclusive jurisdiction over the interpretation of collective bargaining agreements. Compare Slocum v. Delaware, L. \& W.R.R, 339 U.S. 239 (1950), with Crusen v. United Air Lines, 141 F. Supp. 347 (D. Colo.), aff'd per curiam, 239 F.2d 863 (10th Cir. 1956). Limited review of adjustment board procedurcs will be given for losing unions. Compare Ellerd v. Southern Pac. R.R., 241 F.2d 541 (7th Cir. 1957), with Edwards v. Capital Airlines, Inc., 176 F.2d 755, 761 (D.C. Cir.), ccrt. denied, 338 U.S. 885 (1949). The distinction in major and minor disputes is applied. Compare Elgin, J. \& E. Ry. v. Burley, 325 U.S. 711, $722-28$ (1945), veith O'Donnell v. Pan Am. World Airways, Inc., 200 F.2d 929 (2d Cir. 1953). The jurisdiction of the boards will be protected by enjoining strikes over minor disputes. Compare Brotherhood of R.R. Trainmen v. Chicago River \& I.R.R., 353 U.S. 30 (1957), with International Ass'n of Machinists v. Northwest Airlines, Inc., 304 F.2d 206 (8th Cir. 1962), and Northwest Airlines, Inc. v. International Ass'n of Machinists, 179 F. Supp. 825 (D. Minn. 1959). 
similarity of treatment can only be achieved by the incorporation into section 184 of not only subsection $(m)$ but also subsection $(p)$, which undercuts the finality of subsection $(m)$ by providing for broad review in enforcement suits by unions. If subsection ( $p$ ) is not carried over, the scope of review of air system board awards will differ substantially from those of the NRAB, since there will be only limited review of air system board awards. Also, if the National Air Transport Adjustment Board is later established, ${ }^{78}$ the same difference in scope of review will exist between its awards and those of the system boards, since the section providing for the establishment of the NATAB makes clear that its awards are to be enforced in the same manner as those of the NRAB. ${ }^{80}$ These resulting dissimilarities would give pause to a court attempting to exclude the provisions of subsection ( $p$ ) from the federal right of finality in section 184.

The broad standard of review required by subsection $(p)$ for awards favorable to the unions is one of the unforeseen adverse effects on airline unions that a victory for the union in Central Airlines may entail. The unions are seeking a federal right of enforcement to avoid the broad and variegated state standards of review, but the incorporation of subsection ( $P$ ) into section 184 would mean that a standard of review as broad as that of any state, short of a complete trial de novo, would be applied to union enforcement suits. Moreover, the finality denied by subsection ( $p$ ) has been the primary reason for resort to enforcement strikes by unions in the railroad industry. ${ }^{81}$ But a reversal of the Fifth Circuit in Central Airlines and a finding of a federal right of enforcement might deprive airline unions of this principal means used to date to gain compliance with system board awards. If the Supreme Court in the Lotisville \& Nashville ${ }^{82}$ case approves the extension of the doctrine of Chicago River for railroads so as to allow injunctions against enforcement strikes on the theory that the enforcement procedure provided by section 153 First is exclusive, the finding of a federal right of enforcement in section 184 will similarly render enforcement strikes by airline unions subject to injunctions. In short, a victory for the union in Central Airlines may mean that airline unions are to be saddled

79. The possibilities for the establishment of the NATAB are slight, sirce the NRAB is now anything but a rousing success. Disputes may take from five to seven years to settle. See In re Hudson \& M.R.R., 178 F. Supp. 106 (S.D.N.Y. 1959) (letter from Executive Secretary of the NRAB), cert. denied, 361 U.S. 928 (1960); Northrup \& Kahn, supra note 52 , at 556. In light of this situation one district court judge even held that he would give a carrier an injunction against a union strike over a minor dispute only if the carrier and union promised not to send the grievance to the NRAB but instead to submit it to a special adjustment board then in existence. Chicago, M. St. P. \& P.R.R. v. Brotherhood of R.R. Trainmen, 42 C.C.H. Lab. Cas. II 16,918 (E.D. Wis. 1961). Therefore, no one has urged the adoption of a national air board. See Comment, 51 Nw. U.L. REv. 596, 597 (1956).

80. The wording is that the "awards [shall be] made, stated, served and enforced . . . in the same manner and to the same extent as provided with reference to the National Railroad Adjustment Board by section 3 of Title I of this act." 49 Stat. 1189 (1936), 45 U.S.C. $\S 185$ (1958).

81. See Hearings on S. 3463, supra note 55, at 205, 302.

82. See notes 61-62 supra and accompanying text. 
with the internal inconsistency of the interreaction of subsections $(\mathrm{m})$ and $(\mathrm{p})$, while being denied the only alternative method of enforcement, the right to strike.

Conversely, if the Supreme Court affirms the Fifth Circuit's literal reading of section 184-that federal law compels only the establishment of system boards and does not render their awards final and binding as a matter of federal law-it is possible that no injunctions will be allowed against strikes by airline unions over minor grievances. Indeed, the extension of Chicago River to airline union strikes over disputes pending before an air system board ${ }^{83}$ would be questionable, since the basis of the decision in Chicago Rivar was that Congress had provided an exclusive and binding administrative remedy for the settlement of minor disputes. ${ }^{84}$ For the airlines, the settlement would not be binding as a matter of federal law. A court might still hold that, binding or not, the process of adjustment provided by the compulsory establishment of system boards is exclusive and this fact, combined with the policy expressed in the act for the peaceful settlement of disputes, requires that airline unions be enjoined from striking over pending disputes. But even if these strike injunctions are allowed, once an adjustment board decision is given, if the awards are not final and binding as a matter of federal law, there will be no exclusive peaceful means of enforcement provided by the act. Therefore, the basis for enjoining the enforcement strike would not be present. Thus, an affirmance of the Fifth Circuit on the ground that awards of air system boards are not final and binding by virtue of federal law would probably leave the airline unions in possession of their most powerful enforcement weapon, the strike, and would seem to leave the unions with as satisfactory a standard of review in state courts as they would get by virtue of section 153 First $(p)$.

Indeed, though a right of federal enforcement would be denied the airline unions by an affirmance of the Fifth Circuit, under the federal standard imposed by that court in Sigfred v. Pan American World Airways, Inc.85 the unions would face a far more limited standard of review for favorable awards than would be afforded by the inclusion in section 184 of subsection (p). But a finding that it is not federal law but only the terms of the contract between the parties that makes the awards of air system boards final and binding casts doubt upon the validity of the Fifth Circuit's holding in Sigfred and thus the continued applicability of a limited federal standard of review to airline system board awards, either in state courts or federal courts sitting under diversity jurisdiction. For it is difficult to see how federal law makes the awards fintal and binding for the purpose of judicial review and not final and binding for the purpose of federal jurisdiction. And, if the effect to be afforded the awards is solely a matter of contract between the parties, as a denial of finality conferred by section 184 would imply, there would appear to be no basis in the

83. Northwest Airlines, Inc. v. International Ass'n of Machinists, 178 F. Supp. 825 (D. Minn. 1959).

84. See note 60 supra.

85. See notes 16-19 supra and accompanying text. 
Railway Labor Act for establishing a federal standard to govern review. If there is no federal law upon which to base a federal standard of review, varying state laws of review will govern suits to enforce awards of air system boards. ${ }^{86}$ As a result, the problem earlier referred to of the varying state interpretations of the federal standard of review will be replaced by the more disturbing problem of the states imposing their own standards of review. This will grant the carriers an even greater possibility of finding a court that will be likely to set aside a particular award.

Thus, the airline unions have little to gain and perhaps much to lose from either a decision granting a federal forum for the enforcement of air system board awards but imposing the broad review of subsection ( $p$ ), or a decision holding that whatever weight is to be given to system board awards is to be a result only of the terms of the particular contract between the parties. Nor will either decision further the goal of encouraging the prompt, orderly, and peaceful settlement of labor-management disputes. Denying any weight to system board awards will both encourage and allow enforcement strikes, while granting federal enforcement with broad review will require the union virtually to relitigate all favorable awards and will impose on federal courts a corresponding burden of resolving these disputes. These resolutions will be neither peaceful nor prompt. The most desirable solution would be one that assured greater uniformity in the standards governing the enforcement of adjustment board awards in the interstate airline industry by granting federal jurisdiction, that assured the effectiveness of the system board process by granting limited judicial review, and that assured the peaceful settlement of disputes by enjoining strikes used either to resolve minor disputes or to enforce system board awards. This result can be reached by reversing the Fifth Circuit in Central Airlines on the ground that subsection $(m)$-and only subsection $(m)$-is to be incorporated in section 184. Another possible ground for reaching this result is to ignore the intended similar treatment of disputes in the airline and railroad industries and view section 184 in isolation from the procedures of section 153 First. Then it may reasonably be concluded that since federal law compels the establishment of airline system boards to settle disputes effectively and peacefully, the effectuation of this policy requires that federal courts guarantee the finality of the awards of air system boards. ${ }^{87}$ The problem with either rationale is that

86. For a discussion of the varying standards applied by states see Note, Judicial Review of Arbitration Awards ont the Mferits, 63 HARv. I. Rev. 681 (1950); Carb, The Need for Uniform Laws of Arbitration, 15 Bus. LAw 37 (1959). Also see examples cited in Brief for Petitioner, pp. 28-29, International Ass'm of Machinists v. Central Airlines, Inc, 295 F.2d 209 (5th Cir. 1961), cert. granted, 369 U.S. 802 (1962).

87. The Fifth Circuit in Sigfred stated:

Congress having required the negotiation of collective bargaining agreements, and the establishment of boards of adjustment to interpret them, we deem it a reasonable corollary thereto that it intended that the scope of review in appeals from those boards should be determined by federal courts applying federal law.

Sigfred v. Pan Am. World Airways, Inc., 230 F.2d 13, 16 (5th Cir.), cert. desied, 351 U.S. 925 (1956). Also compare a similar judicial "interpretation" by the Supreme Court in 
Congress in 1936 appeared to envisage an adjustment procedure for airlines similar to, and not more effective than, that already provided for the railroads. But, if awards of the NRAB-and, if established, the NATAB - are to be entitled to only prima facie weight, dissimilar procedures will be provided when air system board awards are made final and binding in union enforcement suits. Thus, it should be recognized that if the Court is to reach the most desirable solution, it will, in effect, be writing the RLA for airlines as it originally should have been written for both the railroads and the airlines. However this ques* tion is resolved, it is clear that the effects of a determination of this procedural question may be far greater than anyone realized when the union in Central Airlines decided to seek a federal forum for enforcement of an airline system board award.

Textile Workers v. Lincoln Mills, 353 U.S. 448 (1957). For a lengthy criticism of this particular action see Bickel \& Wellington, Legislative Purpose and the Judicial Process: The Lincoln Mills Case, 71 HaRv. L. Rev. 1 (1957). 